\title{
MASTER
}

\section{MEASURES TO REDUCE INDUSTRIAL \\ CONSUMPTION OF PETROLEUM \\ UNDER A SHORT-TERM ENERGY EMERGENCY}

Raymond G. Tessmer, JR., John D'Acierno, and David A. Pilati

February 1979

NATIONAL CENTER FOR ANALYSIS OF ENERGY SYSTEMS

DEPARTMENT OF ENERGY AND ENVIRONMENT

BROOKHAVEN NATIONAL LABORATORY UPTON, NEW YORK 11973 


\section{DISCLAIMER}

This report was prepared as an account of work sponsored by an agency of the United States Government. Neither the United States Government nor any agency Thereof, nor any of their employees, makes any warranty, express or implied, or assumes any legal liability or responsibility for the accuracy, completeness, or usefulness of any information, apparatus, product, or process disclosed, or represents that its use would not infringe privately owned rights. Reference herein to any specific commercial product, process, or service by trade name, trademark, manufacturer, or otherwise does not necessarily constitute or imply its endorsement, recommendation, or favoring by the United States Government or any agency thereof. The views and opinions of authors expressed herein do not necessarily state or reflect those of the United States Government or any agency thereof. 


\section{DISCLAIMER}

Portions of this document may be illegible in electronic image products. Images are produced from the best available original document. 


\title{
MEASURES TO REDUCE INDUSTRIAL CONSUMPTION OF PETROLEUM UNDER A SHORT-TERM ENERGY EMERGENCY
}

\author{
Raymond G. Tessmer, JR., John D'Acierno, and David A. Pilati
}

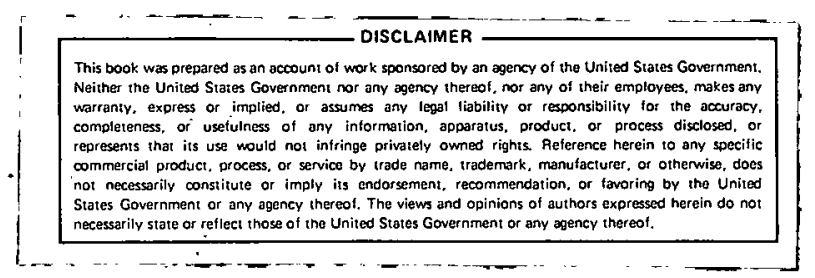

February 1979

\author{
Prepared for the \\ ECONOMIC REGULATORY ADMINISTRATION \\ UNITED STATES DEPARTMENT OF ENERGY
}

by the

NATIONAL CENTER FOR ANALYSIS OF ENERGY SYSTEMS

DEPARTMENT OF ENERGY AND ENVIRONMENT

BROOKHAVEN NATIONAL LABORATORY

ASSOCIATED UNIVERSITIES, INC.

UNDER CONTRACT NO. DE-ACO2-76CH00016 WITH THE UNITED STATES DEPARTMENT OF ENERGY 


\section{DISS.I.ATMF.R}

This book was prepared as an account of work sponsored by an agency of the United States Government. Neither the United States Government nor any agency thereof, nor any of their employees, makes any warranty, express or implied, or assumes any

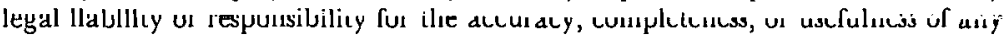
information. apparatus, product, or process disclosed, or represents that its use would not infringe privately owned rights. Keference herein to any specihc commercial product, process, or service by trade name, trademark, manufacturer, or otherwise, does not necessarily constitute or imply its endorsement, recommendation, or favoring by the United States Government or any agency thereof. The views and opinions of authors expressed herein do not necessarily state or reflect those of the United States Government or any agency thereof.

Printed in the United States of America Available from

National Technical Information Service

U.S. Department of Commerce 5285 Port Royal Road Springfield, VA 22161

Price: Printed Copy Microfiche $\$ 3.0$ 
I. Introduction $\ldots \ldots \ldots \ldots \ldots \ldots \ldots \ldots \ldots \ldots \ldots \ldots \ldots \ldots \ldots \ldots \ldots \ldots \ldots \ldots \ldots \ldots$

II. Options and Supportive Governmental Measures ............ 2

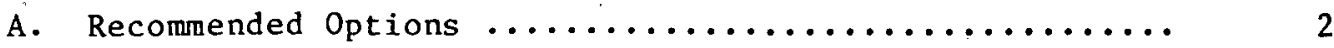

B. Supportive Governmental Measures ................... 12

C. Options Not Recommended ........................ 14

III. Characteristics of Industrial Petroleum

Consumption ................................... 15

A. Chemical Industry $\ldots \ldots \ldots \ldots \ldots \ldots \ldots \ldots \ldots \ldots \ldots \ldots \ldots \ldots \ldots 17$

B. Steel Industry ............................. 18

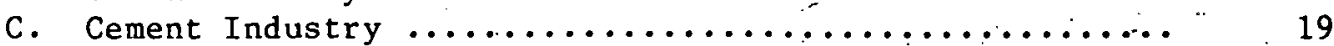

D. Paper Industry ............................... 20

IV. Recommendations for Further Research ................ . 21

\section{TABLES}

1. Energy Content of Exported Goods by Sector ............ 6

2. Major U.S. Exports, $1977 \ldots \ldots \ldots \ldots \ldots \ldots \ldots \ldots \ldots \ldots \ldots \ldots$

3. 1976 Industrial $0 i 1$ Purchases, 10 MMbbl................ 16 
There are significant opportunities for petroleum conservation in the industrial sector in the event of an energy emergency. The mafor governmental options which could be adopted and preliminary estimates of potential petroleum product savings are as follows:

- Remove institutional barriers to fuel switching in industrial boilers and burners: 384 to $407 \mathrm{Mbbl} /$ day.

- Rescind certain air pollution regulations: 19 to $100 \mathrm{Mbbl} / \mathrm{day}$.

- Restrict export of energy-intensive goods: 20 to $60 \mathrm{Mbbl} / \mathrm{day}$.

- Rescind thermal pollution regulations for power plants: 16 to 27 Mbb1/day .

- Remove trade barriers on certain imports.

- Restrict electricity production by industry.

- Restrict export of recyclable materials.

A number of supportive governmental measures are also identified which will indirectly reduce industrial energy consumption and set examples for industrial reaction to an emergency. 


\section{INTRODUCTION}

Brookhaven National Laboratory has undertaken to identify and assess a set of energency conservation $\mathrm{plans}$ to reduce industrial petroleum consumption in the event of an energy emergency. Options for residential, commercial, and commercial transportation energy use are belng developed by Oak Ridge National Laboratory, while the Massachusetts Institute of Technology is considering all other forms of transportation.

These emergency conservation plans are requi red under the Energy Policy and Conservation Act of 1975. "Emergency" is defined as severe supply interruption of Imported fuel, sabotage, or act of God. The plans are to be directed toward demand reduction, not increased supply. Most significant $1 y$, the plans cannot 1 mpose taxes or user fees, cannot price pet roleum, and cannot provide tax rebates.

The most feasible government options identified in this program are presented in Section II. Thei $r$ intended objectives, possible energy savings, const raints on adoption and 1mplementation, and economic impacts are briefly discussed. Because the federal government can undertake a leadership role in energy conservation during an emergency, a set of supportive actions at the federal level is also presented and discussed. Additional options identified in this work, but not recommended, are presented in Section II along with reasons for not giving them further consideration.

The bases for many of the recommended options are presented in Section IrT. An exami nation of historical industrial patterns of of 1 consumption identifies the largest users of petroleum products and, thus, where the largest potential for conservation lies. This is followed with industry-specific information which was obtalned from trade associations and several large manufacturers.

This report provides an initial identification of emergency conservation options with a rough analysis of potential costs and benefits. Section IV therefore presents recommendations for further analysis of these options and for the necessary preplanning among federal government agencies and industry. 


\section{RECOMMENDED OPTIONS AND SUPPORTIVE GOVERNMENTAL MEASURES}

\section{A. Recommended Options}

Option \#1. Remove institutional barriers to fuel switching in industrial boflers and burners.

a. Objective. Substitute natural gas, coal, and LPG for petroleum fuels in industrial bollers and burners.

b. Energy Savings.

Up Lu 160 Mbl/day distillate oil

$+210 \mathrm{Mbbl} / \mathrm{day}$ residual oll

- by switching to NG

$+10-22 \mathrm{Mbbl} / \mathrm{day}$ o11

- by switching to coal

$+7-15 \mathrm{Mbbl} / \mathrm{day}$ oll

- by switching to LPG

These savings are taken from estimates in a 1978 report by

Evaluation Research Corp.* Fuel switching capability data are from the Major Fuel Burning Installations File. Switching capability to natural gas (NG) and 1iquefied petroleum gas (LPG) is probably understated if one takes into account multifuel capability in small bollers and other combustion processes and if the current industrial trend to increased multifuel capability continues. Potential oil savings are of course limited to actual availability of additional natural gas and LPG at the time an actual energy emergency occurs. Switching capability to coal ts probably greatly overstated. Because of favorable economics, it is probable that coal is already the overwhelming fuel cholce in boilers with.coal/oil capability.

c. Constraints and Economic Impacts. The major constraines whlch would inhibit industrial fuel switching to NG and LPG are:

1. Limits on excess gas production capacity above the rate of consumption and any necessary additions lu slurage at the timc of the emergency.

2. The amount of gas in storage necessary for peak and winter

use.

\footnotetext{
* A Study of Several Factors Which Bear Upon the Potential Capability of the Private Sector To Cope With an Interruption in 011 Imports, Evaluation Research Corp., Vienna, VA (October 27, 1978 Draft Report).
} 
3. Federal Energy Regulatory Commission rules and regulations concerning the natural gas production and pipeline companies.

4. The governmental review and approval process for imports of natural gas by pipeline and LNG.

5. Pipeline capacities.

The only constraints which could be relaxed in the short run are 3 and 4 , but their effects could be highly significant under an energy emergency. In February 1979, for example, the American Gas Association publicly stated that there was excess gas available equivalent to 700,000 bbl/day of oll, while industrial representatives asserted that they could not purchase additional gas because of certaln federal rules and regulations in effect.* There is thus a need for the federal government to ascertain, prior to an energy emergency; just what regulations could be rescinded for the duration of the emergency or what alternative set of regulations could be quickly implemented to facilitate increased supply and consumption of natural gas in lieu of petroleum products. Likewise, there is a need to have mechanisms in place for quickly facilitating increased NG and LNG imports in accordance with availability from foreign sources. Attention should be primarily addressed to regulations covering wellhead and resale prices and pipeline curtallments in effect.

Economic impacts associated with fuel switching would be small and probably limited to any increased price that firms would have to pay for NG and LPG versus residual or distillate ofl. Additional costs to NG pipeline companies which might arise if traditional geographical shipping patterns were altered would probably be offset by increased sales.

Option 非. Rescind air pollution regulations except during air quality warning or alert.

\section{a. Objectives.}

1. Promote fuel switching to coal and wood by-products.

\footnotetext{
* MacNeil/Lehrer Report, Public Broadcasting System, February 21, 1979.
} 
2. Permit use of coal and wood by-product boller capacity now idle because of air pollution regulations.

3. Increase efficiency of industrial steam and electric generating plants by bypassing pollution control equipment and thereby saving this energy consumption.

4. Enable fuel switching by increasing the avallable supply of electricity.

\section{b. Energy Savings.}

Three (at present) and 16 (In 1983) Mbbl/day residual ofl - by burning avallable wood by-products.

Nine (at present) and 48 (in 1983) Mbbl/day residual ofl - by burnting more coal.

Seven to 21 (at present) and 12 to 36 (in 1983) Mbbl/day residual oil - by bypassing pollution control equi pment.

Energy savings from increased use of wood by-products are estimated by the American Paper Institut.e. Power would be generated in hogged-fuel bollers now sitting idle and by burning $100 \%$ wood in bollers now burning a combination of wood and oil in order to meet at $r$ entssion standards. Industrial data on excess coal-burning boller capacity were not collected; so a very rough estimate of three times the avallable wood-burning capacity is 11 sted in order to reflect the much larger installed coal-fired capacity in indust rial plants.

Energy required to operate Industrial alr pollution equi pment has been estimated by Development. Sciences, Inc.* No Interviews were made to determine which specific pieces of equipment could be bypassed without violating ambient air pollution emergency levels; a conservative assumption is that it would be possible to save only 5 to $15 \%$ of total energy consumed by air pollution equipment. It is al so assumed that only

* U.S. Envi ronmental Protection Agency, First Order Estimates of Energy Requi rements for Pollution Cont rol, pp. 33-40, Wash1 ngton, DC, October 1977 . 
$50 \%$ of this saving would result from a direct reduction in industrial ofl consumption. The other 50\%, not included above, would come from decreased use of coal in industrial bollers.

Given today's environmental control technology, feasible energy savings with this option will no doubt increase over time as environmental regulations become more stringent.

c. Constraints and Economic Impacts. The major constraint on this option is the complicated political process needed to obtain agreement on a set of modified alr pollution regulations which would be implemented in the event of an emergency. Cooperation would be necessary between DOE, EPA, and state environmental control authorities, with more detailed study required of changes in particular regulations, their impact on petroleum savings (by type and grade of petroleum product), and resultant increases in ambient pollutant levels. As for industry 1tself, certain firms might be unwilling to disconnect control equipment, start up idle boiler capacity, or switch to coal and wood by-products unless continued operation in that mode were guaranteed for some minimum length of time. And unless there are guarantees on the maximum amount of permissible emissions or curtailment in the event of air quality warnings and alerts, there may be considerable opposition to this option.

Economic start-up costs of idle boiler capacity and disconnection of in-place pollution control equipment would in general be more than balanced by improved boller efficiency and use of cheaper fuel (coal and wood by-products). Additional consultation is required for a more realistic assessment of the practical cxtcnt to which emission levels could be increased and the resultant energy savings by fuel type.

Option \#3. Restrict exports of energy-intensive goods.

\section{a. Objectives.}

1. Reduce consumption of petroleum products by restricting export of energy-intensive goods. 
2. Reduce consumption of transportation fuels by switching from air to water mode and by delaying large bulk export shipments until energy emergency is over.

3. Reduce export of petroleum products. Reduce export of other fuels to increase the domestic supply available for fuel switching.

b. Energy Savings. Twenty to $60 \mathrm{Mbbl} /$ day residual ofl and kerosene (assuming reduction in transportation energy requirements of 5 to 15\%). Total energy content (direct plus indirect) of selected export goods and services in elther 1967 or 1972 are listed in Table 1.

Table $1 *$

Energy Content of Exported Goods by Sector

\begin{tabular}{|c|c|c|}
\hline Export sector & Energy cont ent, & $10^{12} \mathrm{Btu}$ \\
\hline $\begin{array}{l}\text { Energy } \\
\text { Coal mining } \\
\text { Refined oil products } \\
\text { Crude oil and gas } \\
\text { Gas utilities } \\
\text { Electric utilities }\end{array}$ & $\begin{array}{r}1322 \\
596 \\
252 \\
93 \\
56\end{array}$ & 2319 \\
\hline $\begin{array}{l}\text { Transportation of final goods/services } \\
\text { for export } \\
\text { Water tranoport } \\
\text { Air transport } \\
\text { Rail transport }\end{array}$ & $\begin{array}{l}576 \\
156 \\
130\end{array}$ & 862 \\
\hline Chemicals \& fertilizer & & 735 \\
\hline $\begin{array}{l}\text { Al umi num, st eel, machinery products } \\
\text { Mot or vehicles } \& \text { al rcraft }\end{array}$ & & $\begin{array}{l}354 \\
196\end{array}$ \\
\hline Grains \& cotton & & 162 \\
\hline Pulp \& paper products & & 146 \\
\hline Wholesale trade & & 120 \\
\hline
\end{tabular}


Since annual fluctuations can be great, the larger of etther 1967 or 1972 energy content. is 11 sted for the most energy-intensive sectors. The flgures include all energy forms (fuel, feedstock, and electricity) embodied in the raw materials of production, in transportation of productive inputs, and in the production process.

As discussed below, the most feasible method for reducing energy use in connection with exported goods is to exhort shippers to delay or stretch out overseas shipments of large volume and bulk materials and to substitute ship for air transport. An immediate energy-saving goal might 11 e in the range of 5 to $15 \%$ of transportation energy requi rement (primarily by ships), or .02 to $.06 \mathrm{MMbb1/day}$.

c. Constraints and Economic Impacts. Federal policies directed toward objectives 1 and 3 - restricting exports of fuels and energyIntensive goods - could encounter severe legal problems, especially those designed to stop delivery under contracts already signed. For contracts signed during the emergency, the time lag between placement of orders and an actual effect on ofl consumption at the manufacturing plant is 11kely to be quite long. This would reduce the effectiveness of such policies during a short-term energency. Shortages of particular goods caused by decreased petroleum avallability will probably vary considerably, accordIng to the nature of the emergency and differential impacts across industries and regions. In view of this, it might be more efficient for the private market to ration those particular goods in short supply. On the other hand, policies directed toward objective 2 switching transportation modes and delaying large bulk shipments by ship - might be politically fcasible. The federal government could play a leadership role by suspending or delaying approval of shipments over which it has direct control, e.g., forelgn aid (particularly food, feed grains, and arms) and trade with communist countries. Along with an executive order requiring federal agencies to transport goods by ship cxe ept under anergency sicuarions, such actions would be a powerful political lever in encouraging similar practices by private concerns. Economic costs would be incurred through such delays in trade, but they 
are likely to be small, especially where large quantities of stocks are maintained at consuming locations (e.g., grain, cotton, coal, paper pulp, 1inerboard, steel scrap, timber and wood products, ores) which can be drawn down over the course of the emergency. Waterborne and al rborne exports with the greatest 1977 tonnage levels are listed in Table 2.

Table 2

Major U.S. Exports, 1977*

\begin{tabular}{|c|c|c|c|}
\hline \multicolumn{2}{|c|}{ Waterborne, $10^{9}$ pounds } & \multicolumn{2}{|l|}{ Al rborne, $10^{6}$ pounds } \\
\hline $\begin{array}{l}\text { Cual } \\
\text { Corn } \\
\text { Wheat } \\
\text { Soybeans } \\
\text { Crude fertilizers } \\
\text { Rough wood } \\
\text { Pitch, asphalt, etc. } \\
\text { Animal feed } \\
\text { Wood manufactures } \\
\text { Mfd. fertilizers } \\
\text { Other cereals } \\
\text { Iron \& steel scrap } \\
\text { Inorganic chemicals } \\
\text { Organic chemical.s } \\
\text { Stone, sand, gravel } \\
\text { Oflseed cake, meal } \\
\text { Pulp \& waste paper } \\
\text { Rice }\end{array}$ & $\begin{array}{r}107.8 \\
88.3 \\
52.5 \\
35.6 \\
28.0 \\
25.0 \\
17.3 \\
17.1 \\
16.8 \\
14.6 \\
13.4 \\
10.4 \\
10.0 \\
9.1 \\
8.9 \\
8.8 \\
7.0 \\
5.0\end{array}$ & $\begin{array}{l}\text { Office machines } \\
\text { Motor vehicle \& tractor } \\
\text { parts } \\
\text { Instruments \& app. } \\
\text { Telecommunications } \\
\text { equi pment } \\
\text { Al rcraft parts } \\
\text { Nonelectric generating } \\
\text { machinery } \\
\text { Live anl mals } \\
\text { Clothing \& accessories } \\
\text { Meat } \\
\text { Const. mining machinery } \\
\text { Electric power machinery } \\
\text { Printed matter } \\
\text { Records, musical } \\
\text { Instruments } \\
\text { Paper board \& manufactures } \\
\text { Pumps, compressors } \\
\text { Syn. resins, plastic } \\
\text { materlals } \\
\text { Electric met ers } \\
\text { I-C engl nes }\end{array}$ & $\begin{array}{l}50.2 \\
45.0 \\
44.8 \\
42.0 \\
41.4 \\
39.3 \\
38.8 \\
38.6 \\
32.3\end{array}$ \\
\hline
\end{tabular}

*U.S. Dept. of Comnerce, U.S. Exports; Commodity Groupings by Wor1d Area, 1977; Washington, DC, June 1978.

Option \#4. Rusciad thermal pollution regulations for power plants. a. Objective. Substitute non-petroleum-based electricity generation for petroleum-based generation. 


\section{b. Energy Savings.}

Sixteen (at present) to 27 (In 1983) Mbb1/day residual oil.

Savings are assumed to be achleved by bypassing mechanical draft cooling towers and discharging higher temperature condenser cooling water Into a nearby water body, where this is physically possible. Current and projected cooling tower capacity and their associated energy requi rements are taken from a Development sciences, Inc. report.* Electrical capacity with cooling towers is estimated at $73.5 \mathrm{GW}$ in 1977 and $120.1 \mathrm{GW}$ in 1983. It is assumed that plant factors average 0.6 and that one-third of the potential energy savings can feasibly be substituted for oil-fired generation. It is assumed that the location of plants with cooling towers that $c$ an be bypassed versus oil-fired plants, and differing temporal profiles of electricity demand, limit feasible substitution to one-third of the potential energy savings.

c. Constraints and Economic Impacts. The primary constraints are federal and state regulations concerning allowable temperature rise in rivers and other bodies of water used for cooling purposes. Such regulations would have to be relaxed for the duration of the energy emergency. While cost savings would accrue to companies bypassing their cooling towers, this would be offset to an extent by intercompany distribution charges to utilities purchasing this electricity as a replacement for their own oil-fired capacity.

Option 非. Remove trade barriers on certain imports.

\section{a. Objectives.}

1. Promote fuel switching to natural gas through increased NG, LPG, and LNG imports.

2. Substitute imports for domestic production of energy-intensive goods - particularly steel, pulp, and paper products.

\footnotetext{
${ }^{\star}$ U.S. Envi ronmental Protection Agency, First Order Estimates of Energy Requi rements for Pollution Control, pp. 15-18, Washington, DC, October 1977.
} 
b. Energy Savings.

Direct oil equivalent to additional natural gas, LPG, and LNG avallable from Canada, Latin America, Algeria, and Indonesia.

$1.6 \mathrm{MMbbl}$ oil per $1 \mathrm{MM}$ tons newsprint imports.

$0.3 \mathrm{MMbb} 1$ oil per $1 \mathrm{MM}$ tons steel imports.

Increased imports of natural gas, liquefied natural gas, and liquefied petroleum gas can be directly substituted for ofl because of the multifuel capacity of many industrial boilers. The limitations present are the avaliable stocks of natural gas (Canada and, within a fow years, Mexico), of propane and butane (primarily Canada), and of LNG (primarily Algeria, Indonesia, and the Middle East).

Inports of certain energy-luleuslve goodo can bo cubetituted fonr domestic production and, thus, will serve to reduce ofl consumption in the affected Industries. Examples of the oil required per unit for U.S. production of steel products and newsprint are shown above. The data are taken from two A.D. Little, Inc. studies.*

c. Constraints and Economic Impacts. Constraints on the use of this option appear at the federal and foreign government and Individual firm levels. Governmental constraints include tariffs, duties, quotas, the trigger price mechanism for steel products, the lengthy review and approval processes for NG and LNG imports, and the export policies of foreign governments. The U.S. duty on imported groundwood paper, for example, is a major factor in limiting its import to an insignificant level. For natural gas, normal procedures of both U.S. and Canadian regulatory authorities are very time consuming. It would therefore be beneficial for both governments to put in place mechanisms for expediting increased sales prior to an actual energy emergency. It is possible that

\footnotetext{
* Industrial Environmental Research Laboratory, U.G.E.P.A., Environmental. Considerations of Selected Energy Conserving Manufacturing Process Options: Vol. V, Pulp and Paper Industry Report, Cincinnati; $0 \mathrm{H}$, December 1976.

Arthur D. Little, Inc., Research, Development, and Demonstration for Energy Conservation: Preliminary Identification of Opportunities in Iron and Steelmaking, Cambridge, MA, January 1978.
} 
additional foreign supplies of energy would be available in the event of an emergency. For example, Canadian exports of NG in 1978 were below allowable levels, and Canadian authorities are presently considering an increase in permissible levels through 1990 because of recent natural gas finds. A significant fraction of our LPG now comes from foreign countries; it is possible that additional supplies would be avallable at various times. However, if advance arrangements are not made with forefgn governments, their reaction during an emergency may be to decrease energy exports to the U.S.

Reaction of industrial firms to increased imports of certain goods is likely to be highly negative, for this would mean a reduction in production levels at U.S. mills. It could be argued that, for capitalintensive goods, the major impact would be on company profits and not on employment. In view of this it might be feasible for federal officials to obtain prior agreement with trade associations and company executives about import measures that would have a large impact on industrial oil consumption, but minimal impact on employment. The impact on cyclical industries would also be smaller because of their established procedures for dealing with a fall in demand.

Option \#6. Restrict Industrial electricity generation where fueled by petroleum products.

a Objective. Substitute non-oil-generated utflity electricity for ofl-fired electricity generation by industry.

b. Energy Savings. Seventeen Mbbl/day distillate and residual oil. Electricity production by industry was $87 \times 10^{9} \mathrm{kWh}$ in 1976 . It is assumed that $20 \%$ of this was oil fired and substitution of purchased electricity (non-oil fired) is only feasible for $20 \%$ of the oil-fired industrial generation.

c. Constraints and Economic Impacts. Complete substitution of purchased for Industrial-generated electricity is not feasible because of cogeneration requil rements for process steam and the fact that certain utilities may also be burning ofl. Improved estimates of feasible substitution will have to be obtained from industry, as relevant data are not published. 
The primary economic impact will be the higher cost of purchased electricity.

Option \#7. Restrict export of recyclable materials.

a. Objective. Reduce energy consumption in steel and paper industries from that required for production of virgin pulp and steel by increased domestic usage of scrap iron and steel and waste paper.

b. Energy Savings. Not estimated.

c. Constraints and Economic. Impacts, The potential for energy savings with this option is great. In 1977 waste paper exports totaled 1.3 miliion tons and iron and steel scrap exports totaled 5.9 million tons. Actual energy savings would not be immediate, however, because of time delays in transportation and in gradual bulldup in use of steel scrap in production processes.

Objections can be expected from scrap dealers because of possible price declines. On the other hand, paper and steel producers would probably favor this option because the drop in export demand would lower the cost of scrap and waste paper to them. In early 1979, for example, steel producers requested export quotas on iron and steel scrap from the Commerce Department because of high world market prices for scrap.

B. Supportive Governmental Measures

Regulatory and approval accions of the federal government have significant impact on industrial fuel mix and levels of usage. Government purchases, trade and tariff policies, forelgn aid shipments, and many other areas of governmental responsibility also direcily lufluetice duiles tic production and levels of energy consumption. Because of large feedbacks to the level of industrial activity, a variety of measures are listed below by which the federal government can effect petroleum conservation in the private sector. The governmenc can additundily set ex... amples which, by drawing upon public relations programs to generate popular support, induce private firms to react in similar fashion even at the expense of short-term company profits. 
1. Recommend and institute fiscal and monetary measures designed to slow the growth rate of the economy. If the energy emergency indeed proves to be great enough to affect the general level of economic activity, this is probably the most equitable policy which the federal government could adopt.

2. Establish an emergency governmental office to handle requests and questions from industry, business, and lower governmental units. Measures needed to alleviate local or firmspecific problems may necessitate coordination of emergency decisions among governmental agencies and offices. An emergency office could enable the necessary coordination as well as serve as a central source of information for the private sector and for state and local governments.

3. Permit pass-through of. higher costs where prices of industrial/ utility outputs are regulated. Given our experience with the Arab oil embargo and the Iranian crisis, oil price rises in the short term will no doubt occur with the onset of an energy emergency. If governmental regulators at the federal and state level do not inhibit quick pass-through of higher costs, this will enhance economic incentives on the supply side and, at the same time, provide price signals to reduce consumption on the demand side. Affected prices include wage/price guidelines or controls as well as energy prices per se.

4. Encourage conservation of other energy forms. To facilitate industrial fuel switching, business and the public must conserve natural gas, LPG, and non-oil-generated electricity, and a public awareness program emphasizing the need for and reasons for such conservation is necessary. The advertising portion of such a program can emphasize conservation of energy-intensive goods and services as well as fuel conservation. Increased recycling of iron, steel, aluminum, copper, paper, tires, and glass should also be promoted.

5. Restrict uranium enrichment and other nonessential (in the short term) energy-intensive operations such as production of military explosives and ammunition. 
6. Recognize and support Implementation of state level energy emergency plans. Many states now have such plans and means for their 1mplementation. Their use can in many instances be more efficient than action at the federal level and more responsive to particular local problems.

7. Shift governmental goods shipment from air and truck to rail and sh1p modes.

C. Options Not Recommended

Option \#8. Close down energy-inefficlent plants.

Reason: This would be highly disruptlve to the communities in which they are located. Decisions on individual plant closings are probably better left to the individual firms. Maintaining production and local employment can then be welghed agalnst the penalty of higher energy consumption per unit of output.

Option \#9. Decrease amounts of oil products that distributors can supply to large customers by specified percentage from previous year.

Reason: This more properly belongs in an allocation plan, which is already assumed to be in effect.

Option \#10. Prohiblt buildup of consumer oil inventories over the amounts in inventory in prior year, and progressively decrease allowable inventory levels.

Reason: Administrative cost of implementation is likely to be very large. Further, during the Arab ofl embargo inventorles actually increased, and the State of Ohio's action during the 1979 Iranian crisis was to urge industries to maintain their oil stocks at maximum levels.

Option \#11. Ban certain types of packaging, and prohibit sale of sma11 package sizes.

Keason: Packaylug lines at planta generally have limited flexthility in the type of packaging material that can be run. Also, prohibition on production of small package sizes would reduce plant capacity - proba- 
bly disproportionately across different firms. These actions could, however, be included as part of a public information program telling consumers how they could help reduce energy consumption.

Option 非12. Prohibit production of certain energy intensive goods, e.g., plastics and synthetic fibers.

Reason: The particular goods which become scarce might vary considerably according to the nature of the energy energency. It is doubtful that good guesses could be made beforehand, and it is probable that resultant plant closings would concentrate the employment and economic impacts in a few communities.

Option 非3. Reduce quality standards on final products, e.g., coatings on paper stock (brightness and printing quality), paper strength.

Reason: It would be difficult to identify specific actions which would significantly reduce petroleum consumption. Quality reduction would probably affect material properties. such as strength, stiffness, or printing quality and create problems with the automatic machinery used to handle reduced-quality materials or problems in the end use of the material.

Option \#14. Restrict road construction and repair.

Reason: Although this would reduce consumption of asphalt, this pet roleum product is not likely to become scarce during an energy emergency. Asphalt exports are large - particularly to Western Europe - and export restrictions might be preferable if there indeed were a shortage. Limiting road construction and repair is likely to be unpopular with the construction industry. In addition to causing unemployment, this restriction would result in vehicular congestion and damage to vehicles.

III. CHARACTERISTICS OF INDUSTRIAL PETROLEUM CONSUMPTION

Oil consumption varies widely across the industrial sectors of the economy. Table 3, which 11sts 1976 sectoral purchases of dist111ate and residual oil at the 3 -digit SIC code level, shows this vividly. The 


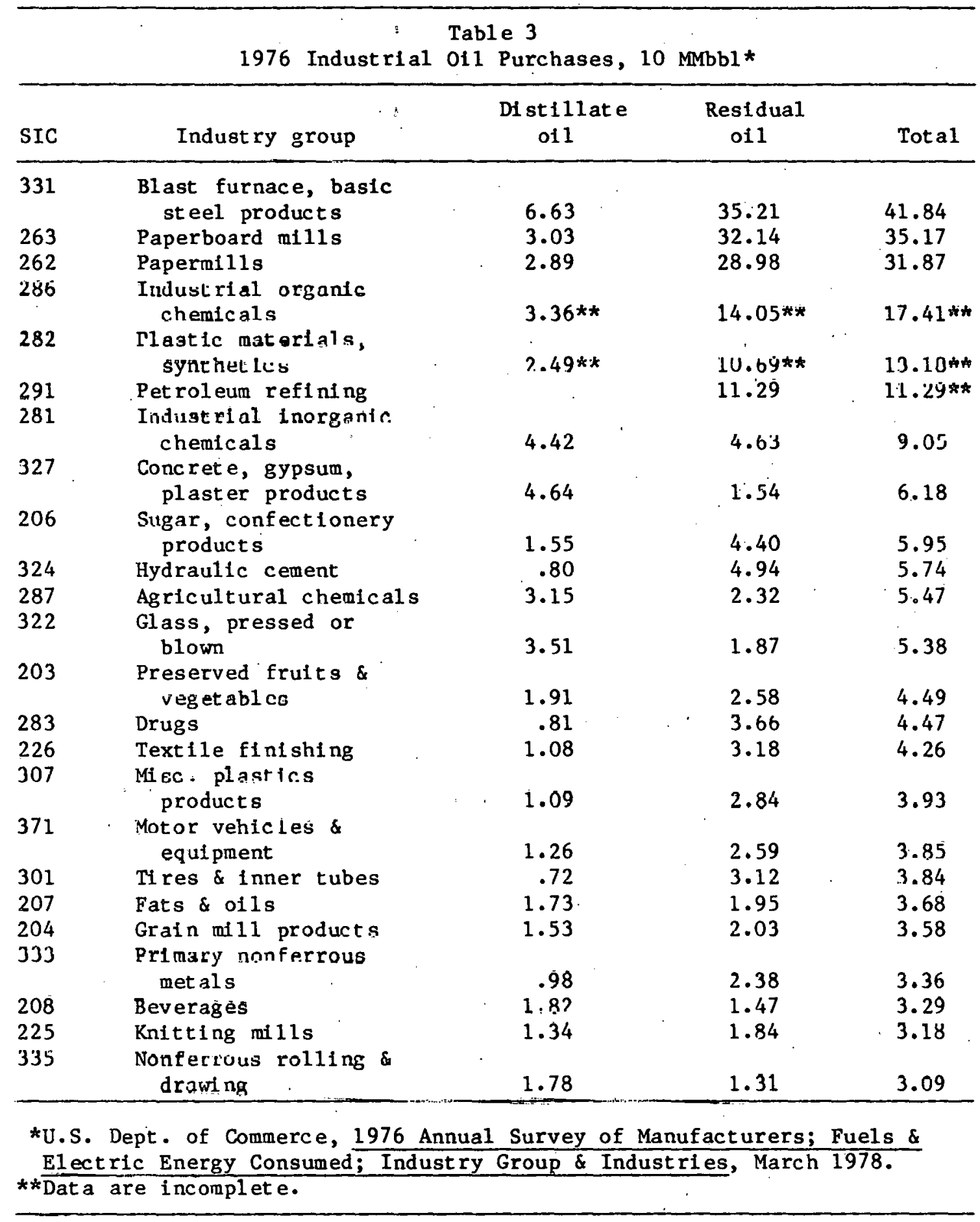


major consumers are, in decreasing order of importance, paper and paperboard mills, basic iron and steel production, chemicals, food and beverages, building products, and plastics. The greatest impact on reducing Industrial ofl consumption can thus be gained through measures directed at these largest users.

The particular characteristics of a future energy emergency may result in shortages of certain specific petroleum products, and not in an across-the-board shortage of all products. It is therefore important to. know the composition of industrial of 1 purchases. For example, $78 \%$ of the purchases shown in Table 3 are for residual ofl and only $22 \%$ are for distillate oil. Emergency measures di rected toward these industries would have much more impact on residual ofl use than on use of disti11ate. It would be instructive to further examine oil use by grade and sulfur content and to assemble corresponding data for other petroleum products such as diesel oll, kerosene, gasoline, LPG, etc.

Since energy-intensive production processes and the potential for energy conservation and fuel switching vary across industries and individual plants, a sample of trade associations and manufacturers has been contacted in order to ascertain the potential for petroleum conservation. Information obtained from the chemical, 1 ron and steel, cement, and paper industries is presented below. This information forms part of the basis for the recommendation of particular energy saving options described in Section II of this report.

A. Chemical Industry*

Recent trends in energy consumption show a drop in the use of natural gas as the primary fuel. From 1972 to 1977, natural gas as a percentage of total fuel use dropped from 47 to $40 \%$ as the industry shifted to increased oil usage. In an energy emergency it is felt that the industry could easily revert to a gas consumption level of $47 \%$ and even as much as $60 \%$ of energy consumed (if available).

*Information sources: (1) Manufacturing Chemists Association, November 1978. (2) U.S. Department of Energy, Voluntary Business Energy Conservation P1 an, Progress Report No. 6, pp. 4-6, DOE/CS-0018/6, April 1978. (3) Dick Barnes, U.S. DOE at ORNL, formerly with Dow Chemical and Shell 0i1, personal communication, November 1978. 
Petroleum products are used chiefly as feedstocks and natural gas is used as fuel for process heat. The data for 1975 reflect this:

$\begin{array}{lccc} & \frac{\text { Feedstock }}{\text { Natural Gas }} & \frac{\text { Fuel }}{80 \%} & \text { Total, } 10^{15} \text { Btu } \\ \text { Petroleum Products } & 20 \% & & 2.0 \\ & 71 \% & 29 \% & 1.4\end{array}$

Natural gas use for feedstock cannot be increased easily in a pet roleum energy emergency. However, if natural gas were avaliable, pet roleum consumption could be lessened by up to $29 \%$ by switching power plants to gas. The industry does not have a plan to shut down production lines whirh use netroleum feedstocks in an emergency. There may be plans in individual plants to shut down some processes which consume oll, bul inily when production can be made up easily at a later date.

The chemical industry's voluntary plan to reduce energy consumption has been successful. Since 1972, energy consumption per unit of output has dropped 12\%, equival ent to a reduction of $206 \mathrm{Mbbl} /$ day. It is felt that there is little room to conserve energy under a short-term emergency, especially petroleum products, through improved maintenance or other such conservation efforts.

Many of the chemical plants are along the Gulf and California coasts where there has been a glut of domestic ofl. The industry could keep these plants on stream without major cutbacks during an energy energency, assuming that domestic ofl is not rationed to other areas.

In summary, the best way the industry could save without sacrifice in production and employment is to switch away from ofl to natural zas fuel for power plants. By cutting back of 1 consumption 1.5 and $29 \%$ the savings would correspond to 93 and $180 \mathrm{Mbbl} /$ day, based on 1975 data.

B. St eel Industry*

St nce 1972 the steel industry has cut back natural gas consumption by switching to petroleum fuels. Data show a drop in gas use from 21.8

\footnotetext{
*Information Sources: (1) Bill Gray, AISI Energy Committee Chairman, Inl and Steel Co., November 1978. (2) U.S. Department of Energy, Voluntary Business Ënergy Conservation Program, Progress Report \#6, DOE/CS-0018/6, Apri1 1978.
} 
to $19.2 \%$ of total energy demand, and a rise in oil use from 6.6 to $8.9 \%$ between 1972 and 1976. Coal and coke have continued to supply the principal energy needs at around $66 \%$. It is felt that oil consumption could be curtailed to the 1972 level or lower, assuming natural gas is aval1able as a replacement. However, a simultaneous drop in both oil and gas usage will effect a roughly proportional drop in production up to some threshold level of ofl curtailment of about 15 to $20 \%$. Fuel switching is the only effective short-term conservation method for the industry.

The greatest amount of oil is used as fuel in reheating furnaces which serve to heat up semifinished shapes of steel prior to rolling and other processing. The blast furnace which is fueled primarily by coke, and the open hearth furnace which can also use natural gas, coke oven gas, or coal tar, both consume residual fuel ofl, but to a much lesser extent than the reheating furnace.

In summary, the impact on residual fuel consumption resulting from a 15 to $20 \%$ curtailment corresponds to 15 to $20 \mathrm{Mbbl} /$ day residual fuel

o11. (Total consumption $=100 \mathrm{Mbbl} / \mathrm{day}, 1976$.

C. Cement Industry*

The trend in energy consumption for the cement industry between 1972 and 1976 has been away from natural gas and towards coal as the primary fuel type. Usage of the two fuels has reversed in this period: natural gas dropped from 45 to $32 \%$ of total energy consumption, and coal increased from 36 to 51\%. Oil demand has dropped only marginally from 12 to $10 \%$. The bulk of the oil used is bunker $\mathrm{C}$ oll for kilns in several plants.

The $k i l n$ is the energy intensive processing step in cement production. Currently, only $2 \%$ of total clinker (product from the kiln) capacity relies on oil. Six plants located in Hawail, Maine, Pennsylvania, and New York consume about $118 \mathrm{Mbbl} /$ day of o1l. Data for the entire Industry are:

*Information Sources: (1) Personal Communication, John Wilson, MartinMaretta Cement, Bethesda, MD., November 1978; (2) Don Peterson, MartinMarietta Cement, Martinsburg, WV, November 1978. (3) Portland Cement Association, in Voluntary Business Energy Conservation Program, Progress Report \#6, DOE/CS-0018/6, Apr11 1978. 
Fuel Capac1ty

Coal

Coal/gas

Coal/o11/gas

0i1/gas

Coal/o11

Gas

어1
No. of Plants

44

41

23

18

16

10

$\frac{6}{158}$
\% Total Capacity

29

23

17

13

13

3

$\frac{2}{100}$

Shutting down oll-fueled kiln plants would not severely affect supply, except in Hawali where there are no other plants.

A wet process concrete plant consumes 5.5 to $6.0 \mathrm{MMBC} / \mathrm{ton}$ of $\mathrm{Flu}$ ished product. Energy is one of the biggest costs in the manufacture of cement, accounting for 25 to $38 \%$ of the selling price. Fuel for the coal-fired $k i l n$ comprises $88 \%$ of total energy use with the remalnder composed of electricity, $10 \%$, and diesel fuel oil, $2 \%$. Electricity is used chiefly for power grinding equipment, and the industry has done as much as it can to shift electrical consumption to off-peak hours. Any further shift will result in a drop in production rate and, most important, poorquality product caused by discontinuity in product shape when the finish grind is performed intermittently. Diesel fuel ofl is necessary in drilling for blasting and in quarrying the rock (raw material).

In summary, the most effective way to reduce petroleum consumption (bunker $\mathrm{C}$ ofi.) in the industry is for all plants which currently consume oll to shift to coal- or gas-fired kd ins, and then to cut back or shut down the six additional plants which rely on crude oll only for the kiln. The potential savings 1 s $118 \mathrm{Mbbl} /$ day.

\section{Paper Industry*}

Oil fuels are used in three primary boller types plus the lime kiln. Together they account for most of the demand in this industry:

Hogged-fuel boiler (combination wood by-products and oil),

Power boller,

Recovery boller.

*Information Sources: (1) Personal Communication, Jeffrey Duke, American Paper Institute, November 1978. (2) Personal Cummunication, Bob Jameson, Weyerhauser, November 1978. 
The lime kiln and power boiler are the two biggest consumers. As a rough estimate, 10 to $40 \%$ of o1l use in these processes could be switched to natural gas without side effects.

Although hogged-fuel boiler use is small, the energy produced here and in the recovery boilers which recover energy from lignin account for $44 \%$ of total energy requirements in the industry. This amount could increase if emission controls were slackened. The present standard is $1 / 10$ 1b particulate emission/MMBtu fuel heat value, corresponding to 0.2 grains/ft ${ }^{3}$ stack gas. This is accomplished by using one or two cyclones to scrub stack gases. To meet this EPA air emission standard, much of the excess wood by-products is now used for land fill instead of power generation with an energy equivalent of $1 \mathrm{MMbbl} /$ year oil. The proposed standard in 6 months is .04 grains $/ \mathrm{ft}^{3}$, which would result in a 25-30\% cutback in hogged-fuel boller capacity. Under this standard Weyerhauser alone will need to purchase additional electricity equivalent to $6 \mathrm{MMbb}$ oil/year, assuming generation is from oil-fired power plants. In addition, the company would have to install medium-efficiency wet scrubbers.

\section{RECOMMENDATIONS FOR FURTHER RESEARCH}

This study represents a preliminary identification of significant opportunities for petroleum conservation in the industrial sector in the event of an energy emergency. It is recommended that more detailed analyses of energy savings, economic impacts, and 1ikely acceptance of the measures by industry be performed through additional consultation with trade associations and large manufacturers. Additional input and cooperation from federal and state governmental agencies are required in chose areas for which regulations and rules would have to be relaxed or changed. Changes in existing government regulations and procedures should be identified and agreed upon in advance of an actual emergency so that reaction can be swift and flexible, depending on the particular nature of the emergency. Flexibility and confidence in the value (in terms of energy saved) of particular options can also be increased by improving the detail of successive analyses in regard to specific types and grades (i.e., sulfur content of residual oil consumed) of specific petroleum products, transportation requirements for industrial fuels (including location of sources of supply), locational patterns of fuel.demand, and disproportionate economic impacts across different firms. 